\title{
Analysis of Perceptions of Driver Abilities and Behaviors in Urban Transportation with Respect to Gender Identity
}

\author{
Seher Özkazanç ${ }^{1 \odot}$ \\ ${ }^{1}$ Assist. Prof. Dr., Faculty of Engineering and Architecture, Necmettin Erbakan University, Konya, Turkey. (Principal contact \\ for editorial correspondence), Email: sozkazanc@erbakan.edu.tr
}

\begin{abstract}
Purpose

Gender inequality is a significant social problem of urban transportation planning. In this context, the main purpose of this study is to determine the stereotypes about the genders of drivers in Turkey. Additionally, the study also aims to reveal the relationship between the talents and behaviors of drivers and gender perceptions.

Design/Methodology/Approach

This study used a hybrid model which allows the use of qualitative and quantitative methods together. The survey method and focus group meetings were utilized at the stage of data collection. In the study, the quota sampling method was applied. The sample consisted of 1239 participants who lived in the province of Konya in Turkey, had a driver's license, drove more than 10 minutes a day and were between 18 and 68 years old. The questionnaires presented to the participants consisted of three parts. The first part included items on the demographic structure of the sample and driving information, the second part included the female driver evaluation form, and the third part included the male driver evaluation form. These driver evaluation forms were prepared as Likert-type scales in the form of a 37-item sets of perception/bias created by benefiting from the literature and focus group interviews.

Findings

Men are perceived more positively in terms of vehicle maintenance and driving ability. It is stated that female drivers have more positive driving behaviors than male drivers. The participants who are female, university graduates or whose spouse drives the car have biases that are significantly free from gendered role attitudes.

\section{Research Limitations/Implications}

The fact that the study was conducted only in a sample from Konya and the small number of focus groups that were interviewed constituted the limitations of the study.

\section{Social/Practical Implications}

Gender inequality is a significant social problem of urban transportation planning. To achieve social integration and utilize urban services more effectively, it is needed to try to eliminate prejudices/negative perceptions towards gender in traffic.

Originality/Value

This study, where determination of stereotypes regarding the gender of drivers and driver perceptions were focused on, is significant especially in terms of the literature in Turkish and has a unique value.
\end{abstract}

Keywords: Driver perceptions, driver stereotypes, gender differences, gender-based biases 


\section{INTRODUCTION}

Participation in urban activities, and in local transportation as a result of this, play an important role in social integration. When local transportation modes are analyzed, it is seen that the use of private vehicles is often a desired type of transportation because it provides flexibility (freedom) in terms of time and space to individuals. When urban sprawl is added to this situation, the demand for private vehicles is increasing day by day. Especially in cities where public transportation is insufficient, and urban activities are at long distances, this increase also brings traffic accidents with it. While the attitudes of drivers towards traffic safety and "being a good driver" gain importance in incity transportation, criteria for a good driver are mostly associated with gender. Accordingly, Kose (2014) stated that automobile culture consists of a system of universal and similar rules, and being a good driver carries national and gender-related characteristics. In the literature, it is seen that, although national characteristics differ, perceptions based on the gender of drivers are mostly similar (Lajunen et al., 2004; Ozkan et al., 2006; Warner et al., 2011). For example, in most cultures, there is a cliché (stereotype) that women are careless and bad drivers (Granié \& Papafava, 2011; Berger, 1986; Glendon et al., 1996; Yeung \& von Hippel, 2008). On the other hand, not complying with traffic rules (high speed, not wearing seatbelt, running red lights, harassing other drivers) and performing risky behaviors are associated with masculinity. Additionally, in the literature, the dominant view is that men are agile and brave drivers, while women are held back and hesitant (Unal et al., 2017). This way, both driving talent and risk are associated with gender. Nevertheless, perceptions that men are better drivers contradict accident statistics. Accordingly, the rate of male drivers to be involved in a fatal accident is higher than that among female drivers (the Insurance Institute for Highway Safety reported that $71 \%$ of those dying in motorized vehicle accidents are male drivers (IIHS, 2017), while this rate is $76.3 \%$ in Turkey (EGM, 2016)).

In line with this information, the main purpose of this study is to determine various stereotypes towards the gender of drivers in Turkey. In this context, first of all, explicit and implicit biases were investigated. A review of the literature was utilized for explicit biases, while the focus group meetings were used for implicit biases. As a result of this research, a 37-item questionnaire form was created (Table 1). This questionnaire applied in the Konya sample revealed driver skill and behavior perceptions based on gender.

\section{Gendered Role Attitudes towards Driver Behaviors, Traffic Safety and Risk-Taking: Explicit Biases}

The mortality rate due to road traffic accidents was $18 \%$ per 100,000 people, and about $80 \%$ of these deaths occurred in middle-income countries, which make up $72.2 \%$ of the world's population (WHO, 2013). This difference between countries mainly depends on road 
Analysis of Perceptions of Driver Abilities and Behaviors in Urban Transportation with Respect to Gender Identity

infrastructure, traffic density on roads, availability of public transportation and behavioral and demographic factors. Additionally, driving speed, climate and weather conditions, driver behavior and experiences are also effective in traffic accidents (Juhnke et al., 1995). In Turkey, however, a large proportion of road traffic accidents (88.4\%) are seen to be caused by driver mistakes (EGM, 2019). Several variables such as physical and social environment, personal characteristics, age, intercultural difference, gender differences and experience affect driver behavior and mistakes (Hoare, 2007; Stanton \& Salmon, 2009; TeyeKwadjo, 2011). Since this study focuses on the context of gender, it relies on skill, safety and risk-taking dimensions and female and male driver behaviors in the literature research. Regarding driving abilities, the perception that female drivers are seen as unskilled (Glendon et al., 1996), and women have more difficulty in reversing and in parking vehicles is high (Derks et al., 2011; Lawrence \& Richardson, 2005; Wolf et al., 2010). Lack of driving skills for female drivers (compared to male drivers) is associated with panic, unstable and anxious moods, poor speed control and distractibility (Glendon et al., 1996; Lawrence \& Richardson, 2005).

In terms of safety, on the other hand, compared to male drivers, female drivers are seen as driving safer and having less accidents involving death (Akerstedt \& Kecklund, 2001; Kim et al., 2008; Ma \& Yan, 2014; Massie et al., 1995; Santamarina-Rubio et al., 2014; Zhou et al., 2015). Indeed, Rosenbloom et al. (2009) found that male drivers were more dangerous in traffic than female drivers. Likewise, it is known that male drivers display behaviors that will endanger traffic like drunk driving, smoking while driving, improper passing, neglecting traffic rules, not wearing seatbelt, not complying with following distance and not giving way to other vehicles or pedestrians more frequently (Goodman et al., 1991; Massie et al., 1995; Sullman et al., 2017; Tavris et al., 2001). Another security breach is the use of mobile phones by drivers of whom most are males and the use of smartphone apps, social media and shared mobility services cause serious accidents (Caird et al., 2008; Fountas et al., 2019; Gulliver \& Begg, 2004; Klauer et al., 2006; McEvoy et al., 2006; Wang et al., 2010). Examining the risk-taking behavior that has a negative impact on traffic accidents (Bamberg et al., 2003; Parker et al., 1992; Ram \& Chand, 2016; Sabey \& Taylor, 1980), it is seen that, again, men exhibit more aberrant driving in general (Glendon et al., 2014; Rhodes \& Pivik, 2011; Rowe et al., 2015; Wang et al., 2002). Besides, according to findings in the literature, in comparison to female drivers, male drivers are more likely not to let other vehicles pass, to toot their horn frequently and to disturb others by cutting across another driver (Shinar \& Compton, 2004; Stephens \& Sullman, 2015).

\section{Driver Gender in Turkey: Implicit Biases}

The population with a driver's license in Turkey is 27,481,703, and among these, $76.2 \%$ are male, and $23.8 \%$ are female (EGM, 2016). The 
small proportion of female drivers may be associated with the culture, patriarchal social structure and female poverty.

In comparison to developed countries, women's participation in social life by breaking the norms is a newer phenomenon for Turkey. Therefore, female drivers are also a new phenomenon (Unal et al., 2017). Factors such as imposing gender roles at a young age culturally by the family and teaching girls to do housework and boys to drive cars provide men with many years of driving experience. Women, on the other hand, in general, can get behind the wheel only after graduation (Hacisalihoglu, 2017). While this is the case in Turkey, the common perception is that women are bad drivers. Similarly, in their interviews with female drivers and engine operators working in the transportation sector in Ankara in Turkey, Ulutas et al. (2016) determined a prevalent perception that women cannot drive well. They also observed that male drivers displayed rude and belittling attitudes towards their female counterparts. Aycan and Aycan (2014) stated that women were perceived as "drivers endangering traffic". In their study conducted in Trabzon in Turkey, Hacisalihoglu (2017) reported that women were perceived as "drivers who make mistakes".

In the literature in Turkey, studies on the gender of drivers are highly limited. Therefore, in this study, qualitative analysis (including focus group meetings) was carried out to determine various prejudices/perceptions towards the gender of drivers in Turkey.

\section{METHODOLOGY AND DATA COLLECTION}

The study included a hybrid model which allows the use of qualitative and quantitative methods together. The purpose of using a hybrid model was to increase the reliability of the study. In this context, qualitative methods at the stage of data collection and quantitative methods at the stage of analysis were used. To determine gender perceptions regarding driver attitudes and behaviors, in addition to findings in the literature, focus group meetings were utilized. The literature review revealed explicit biases, while the focus group meetings revealed implicit biases. As a result of findings obtained from the literature and biases and perceptions revealed in the focus group meetings, questionnaires were designed (Table 1).

The questionnaires consisted of three parts. The first part included items on the demographic structure of the sample (age, gender, educational status, marital status) and driving information (how often the participant drives per week; driving time; if married, whether the spouse drives). In the second part, there was a 37-item female driver evaluation form, while the third part included a male driver evaluation form consisting of the same questions (Table 1).

With the help of these two forms in the questionnaires, the participants had the opportunity to state their perceptions about the skills and behaviors of their own gender and the opposite gender (for example, the female participants scored both the female and male driver evaluation 
Analysis of Perceptions of Driver Abilities and Behaviors in Urban Transportation with Respect to Gender Identity

forms). A 9-point Likert-type scoring system was applied in these questionnaire forms (1: absolutely disagree, 9: absolutely agree). The reason for preferring 9-point Likert-type scales was that scales consisting of 2, 3 or 4 options are considered to have "the lowest", those consisting of 5 or 6 options are considered to have "moderate", and those consisting of 7-10 options are considered to have "the highest" reliability (Preston \& Colman, 2000). To prevent false readings and facilitate evaluation, only negative sentence patterns were included in the item sentences.

Table 1. Items used in the questionnaire (Women/Men are abbreviated as $\mathrm{W} / \mathrm{M})$

\begin{tabular}{|c|c|c|c|c|c|}
\hline \multicolumn{2}{|c|}{ Item No-Description } & \multirow[b]{2}{*}{$\begin{array}{l}\text { References } \\
\text { Glendon et al., 1996; } \\
\text { Lawrence \& } \\
\text { Richardson, 2005; } \\
\text { Brison, 1990; } \\
\text { Mangiaracina \& } \\
\text { Palumbo, 2007 }\end{array}$} & \multicolumn{2}{|c|}{ Item No-Description } & \multirow{2}{*}{$\begin{array}{l}\text { References } \\
\text { Brison, 1990; } \\
\text { Mangiaracina \& } \\
\text { Palumbo, 2007; } \\
\text { Brookland et al., 2010; } \\
\text { Vanlaar \& Yannis, } 2006\end{array}$} \\
\hline 1 & $\begin{array}{l}\text { W/M drive fast } \\
\text { enough to } \\
\text { endanger traffic }\end{array}$ & & 20 & $\begin{array}{l}\text { W/M } \\
\text { overtake } \\
\text { improperly }\end{array}$ & \\
\hline 2 & $\begin{array}{l}\text { W/M have } \\
\text { difficulty } \\
\text { driving in bad } \\
\text { weather }\end{array}$ & $\begin{array}{l}\text { Akanbi et al., 2009; } \\
\text { Bone \& Mowen, 2006; } \\
\text { Silas et al., } 2011\end{array}$ & 21 & $\begin{array}{l}\text { W/M have } \\
\text { difficulty in } \\
\text { parallel } \\
\text { parking }\end{array}$ & $\begin{array}{l}\text { Derks et al., 2011; } \\
\text { Lawrence \& } \\
\text { Richardson, 2005; Wolf } \\
\text { et al., } 2010\end{array}$ \\
\hline 3 & $\begin{array}{l}\text { W/M panic in } \\
\text { case of } \\
\text { potential } \\
\text { danger }\end{array}$ & $\begin{array}{l}\text { Glendon et al., 1996; } \\
\text { Lawrence \& } \\
\text { Richardson, } 2005\end{array}$ & 22 & $\begin{array}{l}\mathrm{W} / \mathrm{M} \text { do not } \\
\text { give priority } \\
\text { to cyclists }\end{array}$ & $\begin{array}{l}\text { Goodman et al., 1991; } \\
\text { Massie et al., 1995; } \\
\text { Sullman et al., 2017; } \\
\text { Tavris et al., } 2001\end{array}$ \\
\hline 4 & $\begin{array}{l}\text { W/M lack first- } \\
\text { aid knowledge }\end{array}$ & $\begin{array}{l}\text { Akanbi et al., 2009; } \\
\text { Bone \& Mowen, 2006; } \\
\text { Silas et al., } 2011\end{array}$ & 23 & $\begin{array}{l}\text { W/M drive } \\
\text { too close to } \\
\text { the wheel }\end{array}$ & Focus group interview \\
\hline 5 & $\begin{array}{l}\text { W/M do not } \\
\text { know the } \\
\text { meaning of } \\
\text { traffic signs }\end{array}$ & $\begin{array}{l}\text { Akanbi et al., 2009; } \\
\text { Bone \& Mowen, 2006; } \\
\text { Silas et al., } 2011\end{array}$ & 24 & $\begin{array}{l}\text { W/M toot } \\
\text { horn very } \\
\text { often }\end{array}$ & $\begin{array}{l}\text { Shinar \& Compton, } \\
\text { 2004; Stephens \& } \\
\text { Sullman, } 2015\end{array}$ \\
\hline 6 & $\begin{array}{l}\text { W/M do not } \\
\text { notice that their } \\
\text { cars are } \\
\text { malfunctioning }\end{array}$ & Focus group interview & 25 & $\begin{array}{l}\text { W/M delay } \\
\text { their vehicle } \\
\text { controls }\end{array}$ & Focus group interview \\
\hline 7 & $\begin{array}{l}\text { W/M do not let } \\
\text { pedestrians } \\
\text { pass }\end{array}$ & $\begin{array}{l}\text { Goodman et al., 1991; } \\
\text { Massie et al., 1995; } \\
\text { Sullman et al., 2017; } \\
\text { Tavris et al., } 2001\end{array}$ & 26 & $\begin{array}{l}\text { W/M have } \\
\text { difficulty in } \\
\text { driving in } \\
\text { heavy traffic }\end{array}$ & Focus group interview \\
\hline 8 & $\begin{array}{l}\text { W/M's reflexes } \\
\text { are weak while } \\
\text { driving }\end{array}$ & $\begin{array}{l}\text { Glendon et al., 1996; } \\
\text { Lawrence \& } \\
\text { Richardson, } 2005\end{array}$ & 27 & $\begin{array}{l}\text { W/M } \\
\text { constantly } \\
\text { stay on the } \\
\text { left lane }\end{array}$ & Focus group interview \\
\hline 9 & $\begin{array}{l}\text { W/M use } \\
\text { mobile phone } \\
\text { while driving }\end{array}$ & $\begin{array}{l}\text { Caird et al., 2008; } \\
\text { Fountas et al., 2019; } \\
\text { Gulliver \& Begg, 2004; } \\
\text { Klauer et al., 2006; } \\
\text { McEvoy, et al., 2006; } \\
\text { Wang et al., } 2010 \\
\end{array}$ & 28 & $\begin{array}{l}\text { W/M do not } \\
\text { give priority } \\
\text { to other } \\
\text { drivers }\end{array}$ & $\begin{array}{l}\text { Shinar \& Compton, } \\
\text { 2004; Stephens \& } \\
\text { Sullman, } 2015\end{array}$ \\
\hline 10 & $\begin{array}{l}\text { W/M have } \\
\text { difficulty } \\
\text { finding } \\
\text { directions while } \\
\text { driving } \\
\end{array}$ & Focus group interview & 29 & $\begin{array}{l}\text { W/M put on } \\
\text { the brakes } \\
\text { suddenly and } \\
\text { hardly }\end{array}$ & Focus group interview \\
\hline 11 & $\begin{array}{l}\text { W/M are } \\
\text { distracted } \\
\text { quickly while } \\
\text { driving }\end{array}$ & $\begin{array}{l}\text { Glendon et al., 1996; } \\
\text { Lawrence \& } \\
\text { Richardson, } 2005\end{array}$ & 30 & $\begin{array}{l}\text { W/M do not } \\
\text { wear a } \\
\text { seatbelt }\end{array}$ & $\begin{array}{l}\text { Goodman et al., 1991; } \\
\text { Massie et al., 1995; } \\
\text { Sullman et al., 2017; } \\
\text { Tavris et al., } 2001\end{array}$ \\
\hline 12 & $\begin{array}{l}\mathrm{W} / \mathrm{M} \text { drive } \\
\text { slowly enough } \\
\text { to endanger } \\
\text { traffic }\end{array}$ & Focus group interview & 31 & $\begin{array}{l}\text { W/M have } \\
\text { difficulty in } \\
\text { filling an } \\
\text { accident } \\
\text { report }\end{array}$ & Focus group interview \\
\hline
\end{tabular}




\begin{tabular}{|c|c|c|c|c|c|}
\hline 13 & $\begin{array}{l}\text { W/M have } \\
\text { difficulty in } \\
\text { driving in } \\
\text { reverse gear }\end{array}$ & $\begin{array}{l}\text { Derks et al., 2011; } \\
\text { Lawrence \& } \\
\text { Richardson, 2005; } \\
\text { Wolf et al., } 2010 \\
\end{array}$ & 32 & $\begin{array}{l}\text { W/M have } \\
\text { difficulty in } \\
\text { parking in the } \\
\text { right angle } \\
\end{array}$ & $\begin{array}{l}\text { Derks et al., 2011; } \\
\text { Lawrence \& } \\
\text { Richardson, 2005; Wolf } \\
\text { et al., } 2010\end{array}$ \\
\hline 14 & $\begin{array}{l}\text { W/M do not } \\
\text { follow the } \\
\text { traffic lights }\end{array}$ & $\begin{array}{l}\text { Goodman et al., 1991; } \\
\text { Massie et al., 1995; } \\
\text { Sullman et al., 2017; } \\
\text { Tavris et al., } 2001\end{array}$ & 33 & $\begin{array}{l}\text { W/M insult } \\
\text { other drivers } \\
\text { in traffic }\end{array}$ & $\begin{array}{l}\text { Shinar \& Compton, } \\
\text { 2004; Stephens \& } \\
\text { Sullman, } 2015\end{array}$ \\
\hline 15 & $\begin{array}{l}\mathrm{W} / \mathrm{M} \text { are often } \\
\text { involved in } \\
\text { crashes }\end{array}$ & Focus group interview & 34 & $\begin{array}{l}\text { W/M smoke } \\
\text { or drink } \\
\text { alcohol while } \\
\text { driving }\end{array}$ & $\begin{array}{l}\text { IIHS, 2017; Brison, } \\
\text { 1990; Mangiaracina \& } \\
\text { Palumbo, } 2007\end{array}$ \\
\hline 16 & $\begin{array}{l}\text { W/M have } \\
\text { difficulty using } \\
\text { vehicle mirrors }\end{array}$ & Focus group interview & 35 & $\begin{array}{l}\text { W/M have } \\
\text { difficulty in } \\
\text { driving on } \\
\text { their own } \\
\text { lane }\end{array}$ & Focus group interview \\
\hline 17 & $\begin{array}{l}\text { W/M fight in } \\
\text { traffic, insult } \\
\text { other drivers }\end{array}$ & Focus group interview & 36 & $\begin{array}{l}\text { W/M do not } \\
\text { know the } \\
\text { right of way }\end{array}$ & $\begin{array}{l}\text { Akanbi et al., 2009; } \\
\text { Bone \& Mowen, 2006; } \\
\text { Silas et al., } 2011\end{array}$ \\
\hline 18 & $\begin{array}{l}\text { W/M do not } \\
\text { prepare their } \\
\text { cars for climatic } \\
\text { conditions }\end{array}$ & $\begin{array}{l}\text { Akanbi et al., 2009; } \\
\text { Bone \& Mowen, 2006; } \\
\text { Silas et al., } 2011\end{array}$ & 37 & $\begin{array}{l}\text { W/M have } \\
\text { difficulty in } \\
\text { maintaining a } \\
\text { safe following } \\
\text { distance }\end{array}$ & $\begin{array}{l}\text { Goodman et al., 1991; } \\
\text { Massie et al., 1995; } \\
\text { Sullman et al., 2017; } \\
\text { Tavris et al., } 2001\end{array}$ \\
\hline 19 & $\begin{array}{l}\text { W/M forget to } \\
\text { use their turn } \\
\text { signal }\end{array}$ & $\begin{array}{l}\text { Akanbi et al., 2009; } \\
\text { Bone \& Mowen, 2006; } \\
\text { Silas et al., } 2011\end{array}$ & & & \\
\hline
\end{tabular}

In this study, 4 hypotheses were determined and evaluated for detection of perceived attitudes and behaviors (biases) related to driving in the context of gender.

Hypothesis 1. Female drivers are more positive than males while evaluating the driving skills and behaviors of their same-sex drivers.

Hypothesis 2. As age increases, positive perceptions towards female drivers increase.

Hypothesis 3. Gender discrimination towards drivers' abilities and behavior decreases as the level of education increases.

Hypothesis 4. In a driver's assessment, being married and the fact that the wife drives the car reduces gender discrimination.

\section{Study Area and Participants}

Konya, which is the largest city in terms of surface area and 7th in terms of population in Turkey, is an automobile-dependent city due to its widespread settlement pattern and inadequate public transportation systems and was therefore chosen as the case study area. According to the data received from the Konya Provincial Security Directorate, among 818,931 individuals having driving licenses in the Konya city, $76.8 \%$ are male, and $23.2 \%$ are female. Since $88.4 \%$ of the road traffic accidents in Turkey arise from automobile driver mistakes (EGM, 2019), the study is limited to drivers who use an automobile.

To achieve a balanced distribution in the questionnaires (age, education, gender, marital status, duration of driving, etc.), the quota sampling method was applied. According to the questionnaire directives (quotas), each of the interviewers was asked to conduct at least 16 questionnaires, ensure the participation of individuals aged over 18 with Class-B Driving License residing in Konya, ensure that at least 5 of 
the questionnaires shall contain the opposite sex, ensure that there were at least 2 primary, high school and university graduates in the questionnaires, ensure that at least 3 people were married, and their spouse drove, exclude drivers with 1-9 minutes of automobile travel (daily). Due to the quota to be applied, 86 volunteering pollsters conducted more than the 16 questionnaires that were asked of them in public and semi-public spaces and eliminated the forms that did not comply with the directive. The high number of pollsters made it easier to eliminate the incompliant forms. After checking 1376 forms complying with the directive, 137 forms were eliminated due to inconsistent responses. With the remaining 1239 driver forms, the error rate of the sample was determined as 2.78 (in a 95\% confidence interval).

\section{ANALYSIS AND FINDINGS}

The constant comparative analysis method was utilized in the focus group meetings. The main purpose of this analysis method is to reveal the themes in the dataset.

Descriptive statistics were utilized while assessing the questionnaire data. The data were analyzed by using the SPSS 25.0 and AMOS 22.0 programs. In the study, as they would increase the value of the error variance, whether or not outliers were in the examined dataset was checked. The outliers were determined on the Box Plot and removed from the dataset. Compatibility with normal distribution was determined by looking at the Q-Q Plots (Chan, 2003) and skewness and kurtosis values. Data are accepted to have a normal distribution if the skewness and kurtosis values are in the range of \pm 3 (Shao \& Zhou, 2002).

The data of the Likert-type scale for the female driver evaluation form of the questionnaire were normally distributed. Therefore, parametric tests were used. Independent-samples t-test was used for the difference between two groups, and one-way analysis of variance (ANOVA) was used in comparing the mean values of more than two groups. The data of the male driver evaluation form were not normally distributed. Therefore, nonparametric tests were used in the evaluations. MannWhitney U test was used for the difference between two groups, while Kruskal Wallis analysis was used for comparisons of more than two groups. Reliability Analysis was conducted to test the reliability of the items, while Exploratory Factor Analysis (EFA) was performed to test the construct validity, and Confirmatory Factor Analysis (CFA) was performed to test the fit of the model. In the exploratory factor analysis, Kaiser-Meyer-Olkin (KMO) test was applied to test the compatibility of the sample size for factor analysis.

\section{Focus Group Meeting Findings}

As stated in the previous sections of the study, the focus group meetings were held to reveal implicit biases/perceptions towards female and 
male drivers. Additionally, the findings from the focus group interviews were utilized in questionnaire design (Table 1).

The focus group meetings were held with 13 individuals (four male traffic police officers, two female transportation planners, two male and two female driving instructors, two male bus drivers). In the interviews, it was determined that perceptions regarding drivers differed based on the group characteristics. For example, women complained of the following biases against their same-sex drivers: frequently being involved in crashes, using mirrors for putting on make-up, not being able to step on the pedals because of their short height and adjusting the seat forward and driving very close to the wheel, failure to stay on their lanes and constant improper use of the left lane. Other issues that were mentioned were: seeing women at the wheel bothers many people in the society, frequently being exposed to verbal or physical harassment, facing a cynical attitude towards their mistake, in the event of the presence of a male on the passenger seat, being criticized for the man not driving the car.

The male bus drivers and traffic instructors stated the following for female drivers: women cannot notice that their vehicles are malfunctioning, they cannot make inspection and conduct maintenance of their cars, they cannot fill the accident report (or they fill them incorrectly), they have a weak sense of direction, they fuss in heavy traffic and have difficulty driving, and therefore, they are exposed to horns, they put on the brakes unexpectedly.

Traffic police officers, on the other hand, stated that some of the listed biases were actually valid for both genders. Serious driving problems considered valid for both genders were as follows: failure to prepare vehicles for harsh climate conditions, increased accidents in bad weather, forgetting traffic signs and first aid information only memorized immediately after passing the driving license exam, not knowing the right of way rules, not using their turn signals. Unfortunately, poor road conditions, lack of vehicle maintenance and traffic culture are factors that contribute to accidents involving death (Akanbi et al., 2009; Bone \& Mowen, 2006; Silas et al., 2011).

To sum up, there are many stereotypes for male and female drivers, and while these stereotypes cause various perceptions in individuals, they turn into different attitudes and behaviors in traffic.

\section{Questionnaire Findings}

With their ages varying in the range of 18-68 years, 1239 drivers participated in the questionnaire. In the assessment of the demographic data, it was observed that the majority consisted of individuals at the ages of 18-34 (68.6\%), men (57.0\%), high school graduates (41.0\%) and single individuals (51.1\%) (Table 2). 
Analysis of Perceptions of Driver Abilities and Behaviors in Urban Transportation with Respect to Gender Identity

Table 2. Distribution of participants by demographic characteristics

\begin{tabular}{llcc}
\hline Variables & & $\mathbf{n}$ & $\mathbf{\%}$ \\
\hline Age & 18-24 years & 450 & 36.3 \\
\cline { 2 - 4 } & 25-34 years & 400 & 32.3 \\
\cline { 2 - 4 } & 35-44 years & 242 & 19.5 \\
\cline { 2 - 4 } & 45 and older & 147 & 11.9 \\
\hline \multirow{2}{*}{ Gender } & Female & 533 & 43.0 \\
\cline { 2 - 4 } & Male & 706 & 57.0 \\
\hline \multirow{3}{*}{ Educational Status } & Primary & 189 & 15.3 \\
\cline { 2 - 4 } & High School & 508 & 41.0 \\
\cline { 2 - 4 } & Graduate & 473 & 38.1 \\
\cline { 2 - 4 } & Post-graduate / Doctorate & 69 & 5.6 \\
\hline \multirow{2}{*}{ Marital Status } & Single & 633 & 51.1 \\
\cline { 2 - 4 } & Marries & 558 & 45.0 \\
\cline { 2 - 4 } & Widow / Divorced & 48 & 3.9 \\
\hline \multirow{2}{*}{ Spouse's Driving Status } & Yes & $\mathbf{1 2 3 9}$ & $\mathbf{1 0 0 . 0}$ \\
\cline { 2 - 4 } & No & & \\
\hline Total & & 215 & 38.5 \\
\hline
\end{tabular}

To determine the suitability of the sample size for exploratory factor analysis, Kaiser-Meyer-Olkin (KMO) test was conducted, and the KMO value was found as 0.961 , which indicated that the sample was adequate for factor analysis. When the Bartlett's Sphericity test results were examined, it was seen that the obtained chi-squared value was acceptable $(\chi 2(528)=39358.014 ; \mathrm{p}<0.01)$. In the exploratory factor analysis conducted to reveal the factor pattern of the driver evaluation scale, it was determined that the factor load values were above 0.40 (principal component analysis was chosen as a factoring method, while Varimax rotation, which is one of the orthogonal rotation methods, was chosen). In the analysis made for two factors, it was determined that the factor loads were on the desired level (Acaroglu, 2014). In the results of the Varimax rotations, items 12, 27, 29 and 36 were excluded from the model due to overlapping, and the remaining 33 items were collected under a total of 2 factors. These factors explained $48.081 \%$ of the total variance. In multi-factor patterns, it is considered sufficient that the explained variance is between $40 \%$ and $60 \%$ (Buyukozturk, 2018).

In studies related to the traffic safety of individuals, in general, two factors are addressed. Driver behaviors, which is the first of these factors, describe what drivers do in traffic, focusing on their individual driving styles. Driver abilities focus on what drivers can do (their potentials) (Elander et al., 1993; Parker \& Stradling, 2001). In light of this information, considering the aggregation of items, these factors were named as F1: Driver Ability and Vehicle Maintenance (explained $21.824 \%$ of total variance) and F2: Driver Behaviors (explained $26.257 \%$ of total variance) (Appendix-Table 1).

When the reliability of the answers given by the participants were evaluated separately as scales and dimensions, it was found that the reliability coefficients for the female driver evaluation form indicated good reliability for the first dimension (0.928), for the second dimension 
(0.886) and for the overall scale (0.931). For the male driver evaluation form, it was also found that the reliability coefficients indicated good reliability for the first dimension (0.905), for the second dimension (0.886) and for the overall scale (0.846). The fact that the Cronbach's Alpha values were greater than 0.70 showed that the scales that were used were reliable and had good internal consistency (Taber, 2018). Table 3 shows the independent-samples t-test results showing the discriminative powers of all items. The raw scores obtained from each factor were ranked in an ascending sorting, and the mean scores of the groups in the lower $27 \%$ and upper $27 \%$ were compared with the independent-samples t-test. As a result of the comparison, a significant difference was found on the level of $\mathrm{p}<0.05$ for all items. The dimensions of the scale may be stated to be distinctive in the context of measuring the desired quality.

Table 3. Analysis results of the dimensions of the driver evaluation scale

\begin{tabular}{|c|c|c|c|c|c|}
\hline \multicolumn{3}{|c|}{ F1: Driver Ability and Vehicle Maintenance } & \multicolumn{3}{|c|}{ F2: Driver Behaviors } \\
\hline $\begin{array}{l}\text { Item } \\
\text { Number }\end{array}$ & $\begin{array}{l}\text { t } \\
\text { (Lower \% } \\
27^{* *} \text { - Upper } \\
\% 27^{* *} \text { ) }\end{array}$ & $\begin{array}{l}\text { p value } \\
\text { (Lower \% } \\
27^{* *} \text {-Upper } \\
\% 27^{* *} \text { ) }\end{array}$ & $\begin{array}{l}\text { Item } \\
\text { Number }\end{array}$ & $\begin{array}{l}\text { t } \\
\text { (Lower \% } \\
27^{* *} \text { - Upper } \\
\% 27^{* *} \text { ) }\end{array}$ & $\begin{array}{l}\text { p value } \\
\text { (Lower \% } \\
27^{* *} \text {-Upper } \\
\% 27^{* *} \text { ) }\end{array}$ \\
\hline 26 & 16.142 & $0.000^{* * *}$ & 17 & -27.212 & $0.000^{* * *}$ \\
\hline 13 & 19.621 & $0.000^{* * *}$ & 33 & -24.842 & $0.000^{* * *}$ \\
\hline 16 & 13.570 & $0.000^{* * *}$ & 14 & -19.200 & $0.000^{* * *}$ \\
\hline 21 & 17.612 & $0.000 * * *$ & 1 & -28.088 & $0.000 * * *$ \\
\hline 23 & 20.219 & $0.000^{* * *}$ & 30 & -22.250 & $0.000^{* * *}$ \\
\hline 10 & 13.297 & $0.000^{* * *}$ & 20 & -16.930 & $0.000^{* * *}$ \\
\hline 8 & 11.962 & $0.000^{* * *}$ & 34 & -23.522 & $0.000^{* * *}$ \\
\hline 6 & 13.779 & $0.000^{* * *}$ & 28 & -15.177 & $0.000^{* * *}$ \\
\hline 2 & 16.309 & $0.000^{* * *}$ & 7 & -15.972 & $0.000^{* * *}$ \\
\hline 32 & 7.8690 & $0.000^{* * *}$ & 22 & -14.993 & $0.000^{* * *}$ \\
\hline 25 & 14.906 & $0.000^{* * *}$ & 9 & -17.186 & $0.000^{* * *}$ \\
\hline 3 & 15.288 & $0.000^{* * *}$ & 24 & -9.7080 & $0.000^{* * *}$ \\
\hline 31 & 8.0810 & $0.000^{* * *}$ & 19 & -7.1770 & $0.000^{* * *}$ \\
\hline 11 & 12.208 & $0.000^{* * *}$ & 15 & -4.8230 & $0.000^{* * *}$ \\
\hline 35 & 5.0540 & $0.000^{* * *}$ & 4 & -4.3080 & $0.000^{* * *}$ \\
\hline 18 & 3.4330 & $0.000^{* * *}$ & & & \\
\hline 5 & 3.3080 & $0.000^{* * *}$ & & & \\
\hline 37 & 3.8390 & $0.000^{* * *}$ & & & \\
\hline
\end{tabular}

In the Confirmatory Factor analysis, the scale was found to be significant on the level of $\mathrm{p}<0.001$ by the structural equation model result, and the 33 items and two dimensions that constituted the scale were found to be related to the scale construct (Table 4). According to the first level multi-factor analysis results, looking at the goodness-of-fit indices of the driver evaluation scale, it may be stated that all values were on an acceptable level (Ozdamar, 2016).

Table 4. First-level multi-factor model confirmatory factor analysis goodnessof-fit indices of the driver evaluation scale

\begin{tabular}{llllll}
\hline RMSEA & NFI & CFI & IFI & GFI & TLI \\
\hline 0.068 & 0.845 & 0.855 & 0.855 & 0.8510 & 0.844 \\
\hline
\end{tabular}


Figure 1. Model for first level multi factor confirmatory factor analysis of the driver evaluation scale (F1: Driving Ability and Vehicle Maintenance, F2: Driver Behaviors)
Appendix-Table 1 shows the factor loads for each factor, and Figure 1 shows the model for first-level confirmatory factor analysis of the driver evaluation scale. The factor loads were found to be over 0.30 .

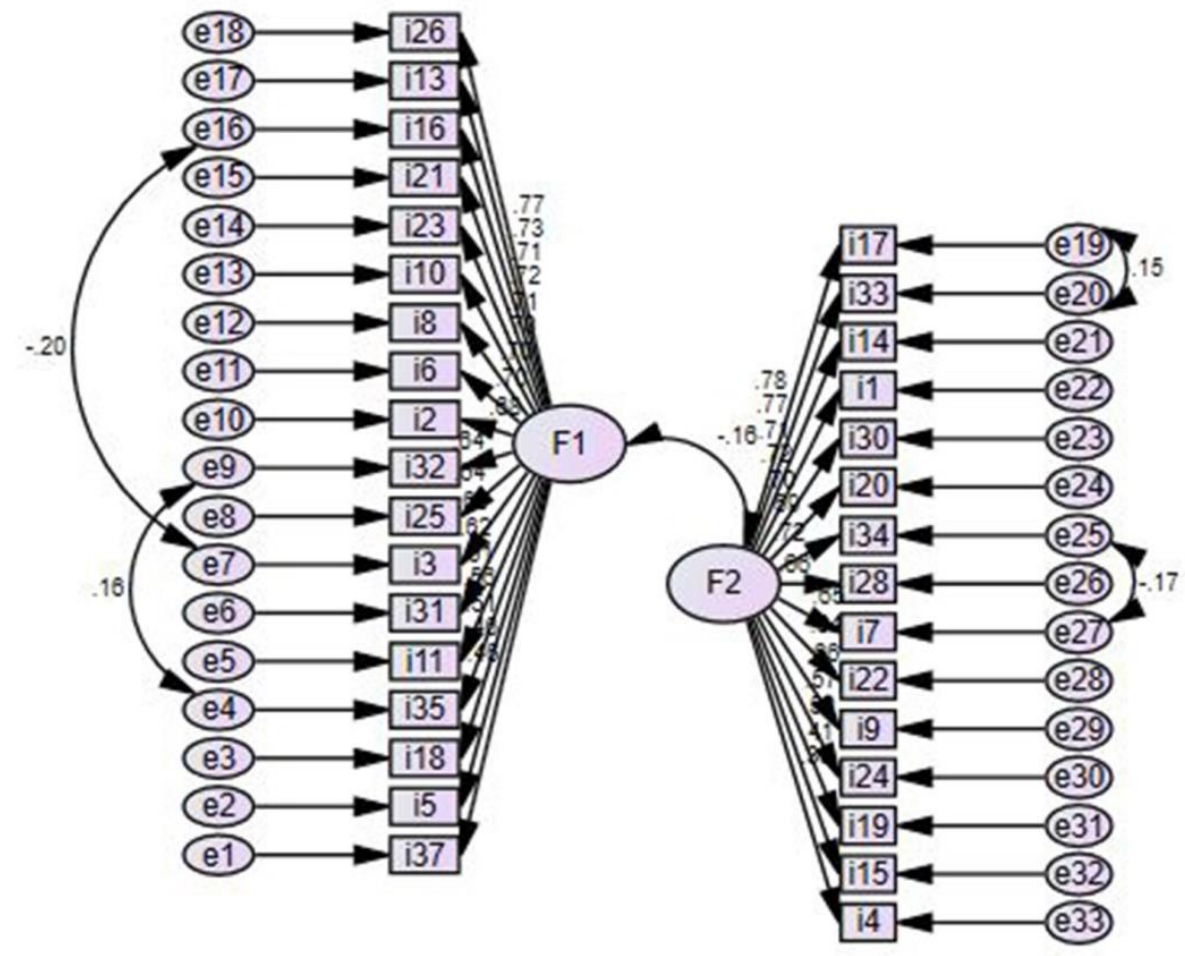

Table 5 shows the descriptive statistics of the driver evaluation scale and its dimensions. There were a total of 33 items in the scale.

Table 5. Descriptive statistics of the driver evaluation scale and its dimensions

\begin{tabular}{llcrr}
\hline Dimensions & $\begin{array}{l}\text { Item } \\
\text { No }\end{array}$ & Min & Max & $\begin{array}{r}\text { Mean士Standard } \\
\text { Deviation }\end{array}$ \\
\hline Female driver evaluation form & 33 & 33.00 & 297.00 & $133.53 \pm 44.38$ \\
\hline Driving Ability and Vehicle & 18 & 18.00 & 162.00 & $84.60 \pm 29.36$ \\
Maintenance & 15 & 15.00 & 135.00 & $48.92 \pm 19.83$ \\
Driver Behaviors & 33 & 33.00 & 297.00 & $138.33 \pm 33.94$ \\
\hline Male driver evaluation form & 18 & 18.00 & 162.00 & $56.36 \pm 24.35$ \\
\hline Driving Ability and Vehicle & 15 & 15.00 & 135.00 & $81.96 \pm 21.35$ \\
Maintenance & & & &
\end{tabular}

\section{Findings on the female driver evaluation form}

One-way ANOVA was applied to compare the mean scores (negative biases increase as the score increases) of the participants in the study by the age, education, marital status and whether their spouses drove. Bonferroni post-hoc test was performed to find the group causing the difference if there was a significant difference $(p<0.05)$. Independentsamples t-test was used to compare the mean scores by the gender variable. 
When the Driving Ability and Vehicle Maintenance dimension scores of the female participants were examined (Table 6), there was a statistically significant difference in the scores based on gender, educational status and spouses' driving status $(\mathrm{p}<0.05)$. Considering the mean scores, the university graduates in comparison to the high school graduates, those whose spouses drove in comparison to those whose spouses did not drive and women in comparison to men provided more positive scores.

Table 6. Comparison of demographic characteristics and mean scores of the Female Driving Ability and Vehicle Maintenance subscales

\begin{tabular}{|c|c|c|c|c|c|c|c|}
\hline & Variables & $\mathbf{n}$ & $\overline{\mathbf{X}}$ & SD & $\mathbf{F} / \mathbf{t}$ & $\mathbf{p}$ & $\begin{array}{l}\text { Multiple } \\
\text { comparison }\end{array}$ \\
\hline \multirow{4}{*}{ Age } & $18-24$ & 450 & 82.55 & 29.52 & \multirow{4}{*}{$\mathrm{F}=1.846$} & \multirow{4}{*}{0.136} & \multirow{4}{*}{-} \\
\hline & $25-34$ & 400 & 84.49 & 29.68 & & & \\
\hline & $35-44$ & 242 & 86.25 & 28.50 & & & \\
\hline & 45 and older & 147 & 88.49 & 29.14 & & & \\
\hline \multirow{2}{*}{ Gender } & Female & 533 & 68.93 & 25.49 & \multirow{2}{*}{$t=-18.421$} & \multirow{2}{*}{$0.000 *$} & \\
\hline & Male & 706 & 96.44 & 26.42 & & & \\
\hline \multirow{4}{*}{ Education } & Primary (1) & 189 & 87.21 & 25.56 & \multirow{4}{*}{$F=3.567$} & \multirow{4}{*}{ 0.014* } & \multirow{4}{*}{$2>3$} \\
\hline & High School (2) & 508 & 86.90 & 28.58 & & & \\
\hline & Graduate (3) & 473 & 81.73 & 30.77 & & & \\
\hline & $\begin{array}{l}\text { Post-graduate/ } \\
\text { Doctorate (4) }\end{array}$ & 69 & 80.27 & 33.06 & & & \\
\hline \multirow{3}{*}{$\begin{array}{l}\text { Marital } \\
\text { Status }\end{array}$} & Single & 633 & 83.07 & 30.31 & \multirow{3}{*}{$\mathrm{F}=1.901$} & \multirow{3}{*}{0.150} & \multirow{3}{*}{-} \\
\hline & Married & 558 & 86.39 & 28.25 & & & \\
\hline & Widow/ Divorced & 48 & 84.39 & 28.80 & & & \\
\hline \multirow{3}{*}{$\begin{array}{l}\text { Whether } \\
\text { Spouse } \\
\text { Drives }\end{array}$} & $\begin{array}{l}\text { No } \\
\text { partner/spouse } \\
(1)\end{array}$ & 681 & 83.18 & 30.01 & \multirow{3}{*}{$\mathrm{F}=14.751$} & \multirow{3}{*}{$0.000 *$} & \multirow{3}{*}{$3>1,3>2$} \\
\hline & $\begin{array}{l}\text { His spouse drives } \\
\text { (2) }\end{array}$ & 343 & 81.39 & 27.00 & & & \\
\hline & $\begin{array}{l}\text { His spouse does } \\
\text { not drive ( } 3 \text { ) }\end{array}$ & 215 & 94.24 & 29.06 & & & \\
\hline
\end{tabular}

$* \mathrm{p}<0.05$

When the mean scores of the dimension of Female Driver Behaviors were analyzed, there was a statistically significant difference based on age, spouses' driving status and gender. There were more negative scores provided by those at the ages of 25-34 in comparison to those at the ages of 18-24, men in comparison to women and those whose spouses did not drive in comparison to those whose spouses drove (Table 7).

When the mean scores of 33 variables in the female's form were analyzed, it was seen that there was a statistically significant difference based on spouse's driving status and gender (Table 8). In the female driver evaluation scale, there were more negative scores among the men in comparison to the women and those whose spouse did not drive in comparison to those who did not have spouses and those whose spouses drove. 
Analysis of Perceptions of Driver Abilities and Behaviors in Urban Transportation with Respect to Gender Identity

Table 7. Comparison of the demographic characteristics and the mean scores of the Female Driver Behaviors dimension

\begin{tabular}{|c|c|c|c|c|c|c|c|}
\hline & Variables & $\mathbf{n}$ & $\overline{\mathbf{X}}$ & SD & $\mathbf{F} / \mathbf{t}$ & $\mathbf{p}$ & $\begin{array}{l}\text { Multiple } \\
\text { comparison }\end{array}$ \\
\hline \multirow{4}{*}{ Age } & $18-24(1)$ & 450 & 47.14 & 18.88 & \multirow{4}{*}{$F=3.199$} & \multirow{4}{*}{$0.023^{*}$} & \multirow{4}{*}{$2>1$} \\
\hline & $25-34(2)$ & 400 & 51.30 & 21.37 & & & \\
\hline & $35-44$ (3) & 242 & 48.58 & 19.28 & & & \\
\hline & 45 and older (4) & 147 & 48.44 & 18.77 & & & \\
\hline \multirow{2}{*}{ Gender } & Female & 533 & 41.43 & 18.45 & \multirow{2}{*}{$\mathrm{t}=-12.213$} & \multirow{2}{*}{$0.000^{*}$} & \\
\hline & Male & 706 & 54.57 & 18.96 & & & \\
\hline \multirow{4}{*}{ Education } & Primary & 189 & 48.09 & 17.59 & \multirow{4}{*}{$F=0.508$} & \multirow{4}{*}{0.677} & \multirow{4}{*}{ - } \\
\hline & High School & 508 & 49.74 & 19.72 & & & \\
\hline & Graduate & 473 & 48.43 & 20.13 & & & \\
\hline & $\begin{array}{l}\text { Post-graduate / } \\
\text { Doctorate }\end{array}$ & 69 & 48.49 & 24.17 & & & \\
\hline \multirow{3}{*}{$\begin{array}{l}\text { Marital } \\
\text { Status }\end{array}$} & Single & 633 & 48.31 & 20.28 & \multirow{3}{*}{$F=0.672$} & \multirow{3}{*}{0.511} & \multirow{3}{*}{ - } \\
\hline & Married & 558 & 49.48 & 19.53 & & & \\
\hline & $\begin{array}{l}\text { Widow / } \\
\text { Divorced } \\
\end{array}$ & 48 & 50.50 & 17.33 & & & \\
\hline \multirow{3}{*}{$\begin{array}{l}\text { Whether } \\
\text { Spouse } \\
\text { Drives }\end{array}$} & $\begin{array}{l}\text { No } \\
\text { partner/spouse } \\
\text { (1) }\end{array}$ & 681 & 48.37 & 20.02 & \multirow{3}{*}{$\mathrm{F}=5.075$} & \multirow{3}{*}{0.006} & \multirow{3}{*}{$3>1,3>2$} \\
\hline & $\begin{array}{l}\text { His spouse drives } \\
(2)\end{array}$ & 343 & 47.60 & 20.01 & & & \\
\hline & $\begin{array}{l}\text { His spouse does } \\
\text { not drive (3) }\end{array}$ & 215 & 52.72 & 18.53 & & & \\
\hline
\end{tabular}

${ }^{*} \mathrm{p}<0.05$

Table 8. Comparison of the demographic characteristics and female driver evaluation form mean scores

\begin{tabular}{|c|c|c|c|c|c|c|c|}
\hline & Variables & $\mathbf{n}$ & $\overline{\mathbf{X}}$ & SD & $\mathbf{F} / \mathbf{t}$ & $\mathbf{p}$ & $\begin{array}{l}\text { Multiple } \\
\text { comparis } \\
\text { on }\end{array}$ \\
\hline \multirow{4}{*}{ Age } & $18-24$ & 450 & 129.70 & 43.28 & \multirow{4}{*}{$\mathrm{F}=1.829$} & \multirow{4}{*}{0.140} & \multirow{4}{*}{ - } \\
\hline & $25-34$ & 400 & 135.80 & 46.26 & & & \\
\hline & $35-44$ & 242 & 134.83 & 43.40 & & & \\
\hline & 45 and older & 147 & 136.94 & 43.71 & & & \\
\hline \multirow{2}{*}{ Gender } & Female & 533 & 110.36 & 40.43 & \multirow{2}{*}{$t=-17.902$} & \multirow{2}{*}{$0.000^{*}$} & \\
\hline & Male & 706 & 151.01 & 38.90 & & & \\
\hline \multirow{4}{*}{$\begin{array}{l}\text { Educatio } \\
\mathrm{n}\end{array}$} & Primary & 189 & 135.30 & 38.15 & \multirow{4}{*}{$F=2.116$} & \multirow{4}{*}{0.096} & \multirow{4}{*}{ - } \\
\hline & High School & 508 & 136.65 & 42.90 & & & \\
\hline & Graduate & 473 & 130.16 & 46.61 & & & \\
\hline & $\begin{array}{l}\text { Post-graduate/ } \\
\text { Doctorate }\end{array}$ & 69 & 128.76 & 53.35 & & & \\
\hline \multirow{3}{*}{$\begin{array}{l}\text { Marital } \\
\text { Status }\end{array}$} & Single & 633 & 131.38 & 45.89 & \multirow{3}{*}{$F=1.533$} & \multirow{3}{*}{0.216} & \multirow{3}{*}{ - } \\
\hline & Married & 558 & 135.87 & 42.81 & & & \\
\hline & Widow / Divorced & 48 & 134.66 & 41.38 & & & \\
\hline \multirow{3}{*}{$\begin{array}{l}\text { Whether } \\
\text { Spouse } \\
\text { Drives }\end{array}$} & $\begin{array}{l}\text { No partner/spouse } \\
\text { (1) }\end{array}$ & 681 & 131.55 & 45.26 & \multirow{3}{*}{$F=12.602$} & \multirow{3}{*}{$0.000^{*}$} & \multirow{3}{*}{$3>1,3>2$} \\
\hline & $\begin{array}{l}\text { His spouse drives } \\
\text { (2) }\end{array}$ & 343 & 129.00 & 42.79 & & & \\
\hline & $\begin{array}{l}\text { His spouse does not } \\
\text { drive (3) }\end{array}$ & 215 & 147.00 & 41.59 & & & \\
\hline
\end{tabular}




\section{Findings on the male driver evaluation form}

Kruskal Wallis analysis was used to compare the mean ranks of the participants in the study by age, education, marital status and spouse's driving status (as mentioned earlier, the responses to the male driver evaluation form were not normally distributed). When a significant difference was found in the variables $(\mathrm{p}<0.05)$, Bonferroni post-hoc test was applied to find the group causing the difference. Mann-Whitney $U$ test was applied to compare the mean rank of the participants by gender variance.

When the Driving Ability and Vehicle Maintenance dimension mean ranks of the male drivers were examined (Table 9), it was seen that there was a statistically significant difference based on age and gender. It was seen that the participants aged between 25 and 34 had higher mean score ranks than those aged between 18 and 24 and those over 45 years old (as the criteria were negatively expressed in the questionnaires, high score ranks should be interpreted as negative and low score ranks should be interpreted as positive perceptions).

Table 9. Comparison of the demographic characteristics and the mean rank of the driving ability and vehicle maintenance dimension of male drivers

\begin{tabular}{|c|c|c|c|c|c|c|}
\hline & Variables & $\mathbf{n}$ & $\begin{array}{l}\text { Mean } \\
\text { Rank }\end{array}$ & $\mathbf{X}^{2} / \mathbf{U}$ & $\mathbf{p}$ & $\begin{array}{l}\text { Multiple } \\
\text { comparison }\end{array}$ \\
\hline \multirow{4}{*}{ Age } & $18-24(1)$ & 450 & 578.75 & \multirow{4}{*}{$X^{2}=20.011$} & \multirow{4}{*}{$0.000 *$} & \multirow{4}{*}{$2>1,2>4$} \\
\hline & $25-34(2)$ & 400 & 669.07 & & & \\
\hline & $35-44(3)$ & 242 & 653.26 & & & \\
\hline & 45 and older (4) & 147 & 558.01 & & & \\
\hline \multirow{2}{*}{ Gender } & Female & 533 & 651.71 & \multirow{2}{*}{$\mathrm{U}=171248.000$} & \multirow{2}{*}{$0.007 *$} & \\
\hline & Male & 706 & 596.06 & & & \\
\hline \multirow{4}{*}{ Education } & Primary & 189 & 616.37 & \multirow{4}{*}{$X^{2}=0.59$} & \multirow{4}{*}{0.996} & \multirow{4}{*}{-} \\
\hline & High School & 508 & 620.77 & & & \\
\hline & Graduate & 473 & 621.66 & & & \\
\hline & $\begin{array}{l}\text { Post-graduate/ } \\
\text { Doctorate }\end{array}$ & 69 & 612.87 & & & \\
\hline \multirow{3}{*}{$\begin{array}{l}\text { Marital } \\
\text { Status }\end{array}$} & Single & 633 & 606.96 & \multirow{3}{*}{$X^{2}=2.648$} & \multirow{3}{*}{0.266} & \multirow{3}{*}{-} \\
\hline & Married & 558 & 629.51 & & & \\
\hline & Widow / Divorced & 48 & 681.40 & & & \\
\hline \multirow{3}{*}{$\begin{array}{l}\text { Whether } \\
\text { Spouse } \\
\text { Drives }\end{array}$} & No partner/spouse & 681 & 609.50 & \multirow{3}{*}{$X^{2}=1.807$} & \multirow{3}{*}{0.405} & \multirow{3}{*}{-} \\
\hline & His spouse drives & 343 & 641.33 & & & \\
\hline & $\begin{array}{l}\text { His spouse does } \\
\text { not drive }\end{array}$ & 215 & 619.22 & & & \\
\hline
\end{tabular}

When the mean ranks of the dimension of Male Driver Driving Behaviors were examined (Table 10), it was seen that gender and spouse's driving status created a statistically significant difference. Besides, the participants who did not have a spouse and those whose spouse drove a car had a higher mean score rank than those whose spouse did not drive, where the female participants also had higher mean score ranks than the male participants. 
Analysis of Perceptions of Driver Abilities and Behaviors in Urban Transportation with Respect to Gender Identity

Table 10. Comparison of the demographic characteristics and mean scores of male driver behaviors dimension

\begin{tabular}{|c|c|c|c|c|c|c|}
\hline & Variables & $\mathbf{n}$ & $\begin{array}{l}\text { Mean } \\
\text { Rank }\end{array}$ & $\mathbf{X}^{2} / \mathbf{U}$ & $\mathbf{p}$ & $\begin{array}{l}\text { Multiple } \\
\text { comparison }\end{array}$ \\
\hline \multirow{4}{*}{ Age } & $18-24$ & 450 & 642.56 & \multirow{4}{*}{$X^{2}=4.161$} & \multirow{4}{*}{0.245} & \multirow{4}{*}{-} \\
\hline & $25-34$ & 400 & 600.90 & & & \\
\hline & $35-44$ & 242 & 628.41 & & & \\
\hline & 45 and older & 147 & 589.08 & & & \\
\hline \multirow{2}{*}{ Gender } & Female & 533 & 682.74 & \multirow{2}{*}{$U=154711.000$} & \multirow{2}{*}{$0.000 *$} & \\
\hline & Male & 706 & 572.64 & & & \\
\hline \multirow{4}{*}{ Education } & Primary & 189 & 578.53 & \multirow{4}{*}{$X^{2}=3.265$} & \multirow{4}{*}{0.353} & \multirow{4}{*}{-} \\
\hline & High School & 508 & 632.88 & & & \\
\hline & Graduate & 473 & 621.17 & & & \\
\hline & $\begin{array}{l}\text { Post-graduate/ } \\
\text { Doctorate }\end{array}$ & 69 & 630.72 & & & \\
\hline \multirow{3}{*}{$\begin{array}{l}\text { Marital } \\
\text { Status }\end{array}$} & Single & 633 & 640.74 & \multirow{3}{*}{$X^{2}=4.370$} & \multirow{3}{*}{0.112} & \multirow{3}{*}{-} \\
\hline & Married & 558 & 598.93 & & & \\
\hline & Widow / Divorced & 48 & 591.39 & & & \\
\hline \multirow{3}{*}{$\begin{array}{l}\text { Whether } \\
\text { Spouse } \\
\text { Drives }\end{array}$} & $\begin{array}{l}\text { No partner/spouse } \\
\text { (1) }\end{array}$ & 681 & 642.22 & \multirow{3}{*}{$X^{2}=11.894$} & \multirow{3}{*}{ 0.003* } & \multirow{3}{*}{$1>3,2>3$} \\
\hline & $\begin{array}{l}\text { His spouse drives } \\
(2)\end{array}$ & 343 & 622.39 & & & \\
\hline & $\begin{array}{l}\text { His spouse does } \\
\text { not drive ( } 3 \text { ) }\end{array}$ & 215 & 545.79 & & & \\
\hline
\end{tabular}

When the mean ranks of the 33 variables in the male driver evaluation form were analyzed, it was seen that there was a statistically significant difference based on age and gender. It was seen that the participants aged between 25 and 34 have higher mean score ranks than those aged 45 years and older, where the female drivers were also more likely to score higher than the male drivers (Table 11).

Table 11. Comparison of the demographic characteristics and the male driver evaluation form score mean ranks

\begin{tabular}{|c|c|c|c|c|c|c|}
\hline & Variables & $\mathbf{n}$ & $\begin{array}{l}\text { Mean } \\
\text { Rank }\end{array}$ & $\mathbf{X}^{2} / \mathbf{U}$ & $\mathbf{p}$ & $\begin{array}{l}\text { Multiple } \\
\text { comparison }\end{array}$ \\
\hline \multirow{4}{*}{ Age } & $18-24(1)$ & 450 & 598.03 & \multirow{4}{*}{$X^{2}=11.147$} & \multirow{4}{*}{ 0.011* } & \multirow{4}{*}{$2>4$} \\
\hline & $25-34(2)$ & 400 & 650.34 & & & \\
\hline & $35-44(3)$ & 242 & 650.18 & & & \\
\hline & 45 and older (4) & 147 & 555.00 & & & \\
\hline \multirow{2}{*}{ Gender } & Female & 533 & 686.61 & \multirow{2}{*}{$\mathrm{U}=152644.500$} & \multirow{2}{*}{$0.000 *$} & \\
\hline & Male & 706 & 569.71 & & & \\
\hline \multirow{4}{*}{ Education } & Primary & 189 & 600.66 & \multirow{4}{*}{$X^{2}=0.805$} & \multirow{4}{*}{0.848} & \multirow{4}{*}{-} \\
\hline & High School & 508 & 624.16 & & & \\
\hline & Graduate & 473 & 625.12 & & & \\
\hline & $\begin{array}{l}\text { Post-graduate/ } \\
\text { Doctorate }\end{array}$ & 69 & 607.26 & & & \\
\hline \multirow{3}{*}{$\begin{array}{l}\text { Marital } \\
\text { Status }\end{array}$} & Single & 633 & 619.73 & \multirow{3}{*}{$X^{2}=0.368$} & \multirow{3}{*}{0.832} & \multirow{3}{*}{-} \\
\hline & Married & 558 & 617.70 & & & \\
\hline & Widow / Divorced & 48 & 650.32 & & & \\
\hline \multirow{3}{*}{$\begin{array}{l}\text { Whether } \\
\text { Spouse } \\
\text { Drives }\end{array}$} & No partner/spouse & 681 & 621.08 & \multirow{3}{*}{$X^{2}=1.943$} & \multirow{3}{*}{0.379} & \multirow{3}{*}{-} \\
\hline & His spouse drives & 343 & 635.34 & & & \\
\hline & $\begin{array}{l}\text { His spouse does } \\
\text { not drive }\end{array}$ & 215 & 592.11 & & & \\
\hline
\end{tabular}

$* \mathrm{p}<0.05$ 
Finally, to test the relationship between the female and male driver evaluation forms of the driver evaluation scale used in the study, a correlation analysis was applied. Based on the correlation analysis results, the female and male driver evaluation forms of the driver evaluation scale appeared to have a positive and significant relationship $(\mathrm{r}=0.114, \mathrm{p}<0.05)$.

\section{EVALUATION OF THE FINDINGS AND DISCUSSION}

According to the literature review, gender has an effect on driving ability and behavior in the traffic environment (Newnam et al., 2014; Soliman et al., 2018). In this context, various items have been determined to reveal gendered role biases. As a result of the factor analysis, the items were collected in two dimensions: Driving Ability and Vehicle Care, and Driver Behaviors. When the Driving Ability and Vehicle Maintenance dimension was examined, it was found that female drivers were scored 47.8 points (a new scoring was made in the range of 0-100; as the score increased, positive bias increased), and male drivers were scored 63.8 points. So, female drivers were evaluated as more nonskilled in comparison to male drivers. In the interviews, it was revealed that consideration of women as unskilled drivers disturbed the female driving instructors more. Indeed, they were doing the same job as males with the same qualifications. In this study, the common belief that men are better drivers and that they are better for vehicle maintenance was similar to the assumption that male drivers are perceived as a master, skilled drivers, but female drivers are not seen as part of their identity, as Ozkan and Lajunen (2006) stated. In addition to this, the significantly positive biases of the participants, who were female, university graduates or whose spouses drove, were determined in the dimension of Female Driver Driving Ability and Vehicle Maintenance (this is a result that supports the hypotheses 1, 3 and 4) which may be associated with empathy.

When the dimension of Driver Behaviors was examined, it was seen that the mean scores differed from the first dimension, and women (63.8 points) were found to be evaluated more positively than men (39.3 points). This result coincides with the result of Esiyok et al. (2007) that highlighted the view that male drivers are more aggressive in traffic than female drivers. As a matter of fact, while aggressive and risky behaviors are considered a masculine feature, being a safe and gentle driver is considered a neutral or feminine feature (Ozkan \& Lajunen, 2006; Sabbour \& Ibrahim, 2010). However, in male-dominated traffic, gendering driver behaviors is a highly problematic situation in terms of traffic safety. Moreover, regarding Driver Behaviors, the participants aged 18-24 had more positive biases than those aged 25-34 (hypothesis 2 was rejected). The female participants had more positive biases than the male participants, and the participants whose spouse drove had 
Analysis of Perceptions of Driver Abilities and Behaviors in Urban Transportation with Respect to Gender Identity

more positive biases than those whose spouse did not drive (this result supported the hypotheses 1 and 4.).

The results of the study revealed that the men evaluated the driving abilities and behaviors of same-sex drivers more positively, while they evaluated female drivers with more bias. On the other hand, the women evaluated the driving abilities and behaviors of same-sex drivers more positively, while they evaluated men at similar scores to other men who participated in the study (Table 1). This finding was similar to the finding of the study by Sibley and Harre (2009). Gendered role attitudes in traffic were reflected in the scores given. Indeed, the male participants defined female drivers as follows (Items with mean score between 5.00-9.00 were taken into consideration): women are drivers who cannot drive in bad weather conditions ( $\overline{\mathrm{x}}: 6.10)$ or in heavy traffic ( $\mathrm{x}: 5.93)$; who panic at a potential danger ( $\overline{\mathrm{x}}: 6.16)$; who have weak reflexes ( $\overline{\mathrm{x}}: 5.29$ ); who cannot find their directions ( $\mathrm{x}: 5.53$ ); who are easily distracted ( $\mathrm{x}: 5.51$ ); who do not care about vehicle mirrors ( $\overline{\mathrm{x}}: 5.27)$; who drive extremely slowly ( $\overline{\mathrm{x}}: 5.73$ ) and very close to the wheel ( $\overline{\mathrm{x}}: 5.91)$; who cannot drive in reverse gear ( $\overline{\mathrm{x}}: 5.96)$, and who delay vehicle inspections ( $\overline{\mathrm{x}}: 5.64)$. The fact that they evaluated same-sex drivers with very low scores in the same items may be considered as an indication that they perceived some attitudes in traffic as feminine. Perhaps, due to this perception, female drivers experience driver anger, disrespect and frustration more than male drivers (Sullman et al., 2007). The male participants identified males as drivers who drive fast enough to endanger traffic ( $\overline{\mathrm{x}}: 6.40)$; who insult others ( $\overline{\mathrm{x}}: 5.69)$ and fight with them ( $\bar{x}: 5.93)$; who often toot their horns ( $\overline{\mathrm{x}}: 5.54)$; who do not give priority the other vehicles ( $\mathrm{x}: 5.19)$; who overtake improperly ( $\overline{\mathrm{x}}: 6.20)$; who smoke, drink alcohol ( $\overline{\mathrm{x}}: 6.20)$ and use their smartphones ( $\overline{\mathrm{x}}: 6.25)$ inside their cars (Appendix-Table 2). This result coincided with angry, risky and rule-violating male driver behaviors reported in the literature (Baxter et al., 1990; Ozkan \& Lajunen, 2005; Rowe et al., 2015). However, in the in-depth interviews, it was revealed that the participants perceived these behaviors as nature of being masculine, and they did not find these behaviors strange. By the roles assigned to women, similar behaviors (getting angry in traffic, fighting with other drivers, using alcohol or drugs in the vehicle, etc.) of women in Turkey are not tolerated by the society and criticized.

\section{LIMITATIONS OF THE STUDY AND RECOMMENDATIONS FOR FUTURE RESEARCH}

In this study, the number of the focus groups interviewed in-depth was very low. Examining gendered role attitudes in traffic with more interviewees shall reveal different problems specific to Turkey which were not included in the questionnaires. Therefore, it is recommended to increase the number of in-depth interviewees regarding the experiences and biases of individuals in traffic in further studies and to 
evaluate these biases using qualitative analysis techniques since they may reveal gendered role attitudes among drivers more clearly.

\section{CONCLUSION}

In in-city transportation, although it is attempted to improve public transportation systems, the demand for automobiles increases day by day. The conveniences in time-space consumption provided by the use of automobiles make them preferable. While increased automobile ownership has led to the spread of most cities, it has made access to urban services more difficult. In Turkey, automobile and driver's license ownership shows serious differences between genders. This difference causes a male-dominated structure in traffic. As a result of roles and social statuses assigned to men and women in the society, women are also excluded from transportation systems, restricted and alienated. In light of this point, sexist attitudes and perceptions preventing women's inclusion in traffic were aimed to be determined. Based on the obtained findings, it was determined that there was a masculine pressure on women. Women are considered to be unskilled/inadequate drivers just because they are women. The fact that women drivers, who are already few in traffic in numbers, are exposed to gendered role attitudes may limit their utilization of other opportunities in the city. Based on this risk, for women to be active participants in the society and to benefit from urban and public services more easily, acts such as imposing the presence of female drivers in traffic on society through raising awareness (advertisements, brochures, short films, etc.), and thus, overcoming the negative prejudice of the society towards women drivers is recommended to eliminate this inequality.

\section{APPENDIX}

Appendix-Table 1. Factor loads obtained as a result of the confirmatory factor analysis regarding the driver evaluation scale

\begin{tabular}{llll}
\hline $\begin{array}{l}\text { F1: Driver Ability and Vehicle } \\
\text { Maintenance }\end{array}$ & \multicolumn{2}{l}{ F2: Driver Behaviors } \\
\hline Item No & Factor Loads & Item No & Factor Loads \\
\hline 26 & 0.775 & 17 & 0.778 \\
13 & 0.727 & 33 & 0.767 \\
16 & 0.714 & 14 & 0.713 \\
21 & 0.714 & 1 & 0.717 \\
23 & 0.718 & 30 & 0.695 \\
10 & 0.698 & 20 & 0.685 \\
8 & 0.696 & 34 & 0.718 \\
6 & 0.697 & 28 & 0.656 \\
2 & 0.676 & 7 & 0.653 \\
32 & 0.636 & 22 & 0.637 \\
25 & 0.640 & 9 & 0.664 \\
3 & 0.659 & 24 & 0.572 \\
31 & 0.615 & 19 & 0.503 \\
11 & 0.609 & 15 & 0.414 \\
35 & 0.565 & 4 & 0.378 \\
18 & 0.508 & & \\
5 & 0.463 & & \\
37 & 0.456 & & \\
\hline
\end{tabular}


Analysis of Perceptions of Driver Abilities and Behaviors in Urban Transportation with Respect to Gender Identity

Appendix-Table 2. Item score means

\begin{tabular}{|c|c|c|c|c|c|c|c|}
\hline \multicolumn{4}{|c|}{ Female driver evaluation form } & \multicolumn{4}{|c|}{ Male driver evaluation form } \\
\hline Item & Female & Male & Total & Item & Female & Male & Total \\
\hline W1 & 2.40 & 3.00 & 2.74 & M1 & 6.58 & 6.26 & 6.40 \\
\hline W2 & 4.49 & 6.10 & 5.41 & M2 & 3.57 & 3.15 & 3.33 \\
\hline W3 & 4.69 & 6.16 & 5.53 & M3 & 3.34 & 3.20 & 3.26 \\
\hline W4 & 2.74 & 3.89 & 3.39 & M4 & 4.41 & 4.01 & 4.18 \\
\hline W5 & 2.63 & 3.82 & 3.31 & M5 & 3.31 & 3.12 & 3.20 \\
\hline W6 & 3.65 & 5.34 & 4.61 & M6 & 2.68 & 2.49 & 2.57 \\
\hline W7 & 2.50 & 3.29 & 2.95 & M7 & 5.31 & 4.62 & 4.92 \\
\hline W8 & 3.53 & 5.29 & 4.53 & M8 & 3.01 & 2.78 & 2.88 \\
\hline W9 & 3.36 & 4.23 & 3.86 & M9 & 6.20 & 6.25 & 6.23 \\
\hline W10 & 3.99 & 5.53 & 4.87 & M10 & 3.29 & 3.11 & 3.19 \\
\hline W11 & 3.87 & 5.51 & 4.80 & M11 & 4.01 & 3.47 & 3.70 \\
\hline W12 & 4.05 & 5.73 & 5.00 & M12 & 2.68 & 2.63 & 2.65 \\
\hline W13 & 4.27 & 5.96 & 5.23 & M13 & 2.94 & 2.83 & 2.88 \\
\hline W14 & 2.22 & 2.81 & 2.55 & M14 & 5.40 & 4.71 & 5.01 \\
\hline W15 & 3.35 & 4.75 & 4.15 & M15 & 5.11 & 4.44 & 4.73 \\
\hline W16 & 3.69 & 5.27 & 4.59 & M16 & 3.06 & 2.93 & 2.98 \\
\hline W17 & 2.38 & 2.83 & 2.64 & M17 & 6.32 & 5.93 & 6.10 \\
\hline W18 & 3.28 & 4.44 & 3.94 & M18 & 3.43 & 3.25 & 3.33 \\
\hline W19 & 2.79 & 4.07 & 3.52 & M19 & 4.91 & 4.43 & 4.64 \\
\hline W20 & 3.26 & 4.44 & 3.93 & M20 & 6.42 & 6.2 & 6.29 \\
\hline W21 & 4.37 & 5.97 & 5.28 & M21 & 2.94 & 2.93 & 2.94 \\
\hline W22 & 2.66 & 3.67 & 3.23 & M22 & 5.22 & 4.68 & 4.91 \\
\hline W23 & 4.17 & 5.91 & 5.16 & M23 & 2.98 & 2.8 & 2.88 \\
\hline W24 & 3.54 & 4.57 & 4.13 & M24 & 5.86 & 5.54 & 5.68 \\
\hline W25 & 4.14 & 5.64 & 5.00 & M25 & 3.46 & 3.07 & 3.24 \\
\hline W26 & 4.08 & 5.93 & 5.14 & M26 & 2.86 & 2.84 & 2.84 \\
\hline W27 & 3.41 & 4.71 & 4.15 & M27 & 4.41 & 4.35 & 4.37 \\
\hline W28 & 2.85 & 4.10 & 3.56 & M28 & 5.83 & 5.19 & 5.46 \\
\hline W29 & 3.72 & 5.41 & 4.68 & M29 & 5.22 & 4.51 & 4.81 \\
\hline W30 & 2.17 & 2.60 & 2.42 & M30 & 5.61 & 4.95 & 5.23 \\
\hline W31 & 4.04 & 5.20 & 4.70 & M31 & 3.24 & 3.09 & 3.16 \\
\hline W32 & 3.69 & 4.89 & 4.38 & M32 & 2.98 & 2.81 & 2.88 \\
\hline W33 & 2.13 & 2.78 & 2.50 & M33 & 6.16 & 5.69 & 5.89 \\
\hline W34 & 3.08 & 3.55 & 3.35 & M34 & 6.46 & 6.20 & 6.31 \\
\hline W35 & 3.09 & 4.52 & 3.91 & M35 & 3.35 & 3.10 & 3.21 \\
\hline W36 & 2.75 & 4.27 & 3.62 & M36 & 4.38 & 3.72 & 4.00 \\
\hline W37 & 3.26 & 4.95 & 4.22 & M37 & 4.09 & 3.75 & 3.90 \\
\hline
\end{tabular}

* The scale ranges from 0 to 9 , negative opinion increases as the score increases.

\section{FINANCIAL DISCLOSURE}

The author declared that this study has received no financial support.

\section{CONFLICT OF INTEREST}

No conflict of interest was declared by the author.

\section{ETHICS COMMITTEE APPROVAL}

Ethics committee approval was not required for this article.

\section{LEGAL PUBLIC/PRIVATE PERMISSIONS}

In this research, the necessary permissions were obtained from the relevant participants (individuals, institutions and organizations) 
during the survey, in-depth interview, focus group interview, observation or experiment.

\section{REFERENCES}

Acaroglu, R. (2014). Revize edilen hemşirelerin mesleki değerleri ölçeği Türkçe formunun güvenirlik ve geçerliği. Florence Nightingale Hemşirelik Dergisi, 22(2), 8-16.

Akanbi, O. G., Charles-Owaba, O. E., Oluleye, A. E. (2009). Human factors in traffic accidents in Lagos, Nigeria. Disaster Prevention and Management: An International Journal, 18(4), 397-409.

Akerstedt, T., Kecklund, G. (2001). Age, gender and early morning highway accidents. Journal of Sleep Research, 10(2), 105-110.

Aycan, Ş., \& Aycan, N.( 2014). Trafiğin yazılı olmayan kurallarının kadın sürücü ayağı. Karayolu Trafik Güvenliği Sempozyumu Bildiriler Kitabı, 63-72.

Bamberg, S., Ajzen, I., Schmidt, P. (2003). Choice of travel mode in the theory of planned behavior: the roles of past behavior, habit, and reasoned action. Basic and Applied Social Psychology, 25(3), 175-187.

Baxter, J. S., Manstead, A. S. R., Stradling, S. G., Campbell, K. A., Reason, J. T., Parker, D. (1990). Social facilitation and driver behavior. British Journal of Psychology, 81(3), 351-360.

357 Berger, M. L. (1986). Women drivers! The emergence of folklore and stereotypic opinions concerning feminine automotive behavior. Women's Studies International Forum, 9(3), 257-263.

Bone, S. A., Mowen, J. C. (2006). Identifying the traits of aggressive and distracted drivers: a hierarchical trait model approach. Journal of Consumer Behaviour, 5(5), 454-464.

Brison, R. J. (1990). Risk of automobile accidents in cigarette smokers. Canadian Journal of Public Health, 81(2), 102-106.

Brookland, R., Begg, D., Langley, J., Ameratunga, S. (2010). Risk perception and risky driving behaviours of adolescents and their parents: New Zealand drivers study. Injury Prevention, 16, A170.

Buyukozturk, S. (2018). Sosyal bilimler için veri analizi el kitabı. Pegem Akademi.

Caird, J. K., Willness, C. R., Steel, P., Scialfa, C. (2008). A meta-analysis of the effects of cell phones on driver performance. Accident Analysis and Prevention, 40(4), 1282-1293.

Chan, Y. H. (2003). Biostatistics 101: data presentation. Singapore Medical Journal, 44(6), 280-285.

Derks, B., Scheepers, D., Van Laar, C., Ellemers, N. (2011). The threat vs. challenge of car parking for women: How self- and group affirmation 
Analysis of Perceptions of Driver Abilities and Behaviors in Urban Transportation with Respect to Gender Identity

affect cardiovascular responses. Journal of Experimental Social Psychology, 47(1), 178-183.

EGM. (2016, June 15). Yllara gore trafik kaza istatistikleri. http://trafik.gov.tr/istatistikler37

EGM. (2019, June 19). Trafik istatistik bulteni. http://www.trafik.gov.tr/kurumlar/trafik.gov.tr/04-

Istatistik/Aylik/nisan19.pdf

Elander, J., West, R., French, D. (1993). Behavioral correlates of individual differences in road-traffic crash risk: An examination of methods and findings. Psychological Bulletin, 113(2), 279.

Esiyok, B., Yasak, Y., Korkusuz, I. (2007). Trafikte ofke ifadesi: Surucu ofke ifadesi envanteri'nin gecerlik ve guvenilirligi. Turk Psikiyatri Dergisi, 18(2),1-13.

Fountas, G., Pantangi, S. S., Hulme, K. F., Anastasopoulos, P. C. (2019). The effects of driver fatigue, gender, and distracted driving on perceived and observed aggressive driving behavior, A correlated grouped random parameters bivariate probit approach. Analytic Methods in Accident Research, 22, 1-15.

Glendon, A. I., Dorn, L., Davies, D. R., Matthews, G., Taylor, R. G. (1996). Age and gender differences in perceived accident likelihood and driver competences. Risk Analysis, 16(6), 755-762.

Glendon, A. I., Mcnally, B., Jarvis, A., Chalmers, S. L., Salisbury, R. L. (2014). Evaluating a novice driver and pre-driver road safety intervention. Accident Analysis and Prevention, 64, 100-110.

Goodman, R. A., Istre, G. R., Jordan, F. B., Herndon, J. L., Kelaghan, J. (1991). Alcohol and fatal injuries in Oklahoma. Journal of Studies on Alcohol, 52(2),156-161.

Granié, M. A., Papafava, E. (2011). Gender stereotypes associated with vehicle driving among French preadolescents and adolescents. Transportation Research Part F: Traffic Psychology and Behaviour, 14(5), 341-353.

Gulliver, P., Begg, D. (2004). Influences during adolescence on perceptions and behaviour related to alcohol use and unsafe driving as young adults. Accident Analysis and Prevention, 36(5), 773-778.

Hacısalihoglu, S. K. (2017). Trabzon trafiginde kadın surucu olmak. İmgelem, 1(1), 61-88.

Hoare, I. A. (2007). Attitudinal factors related to driving behaviors of young adults in Belize: An application of the precaution adoption process model. Graduate Theses and Dissertations.

IIHS. (2017, June 11). Fatality statistics. https://www.iihs.org/topics/fat ality-statistics/detail/gender 
Juhnke, G. A., Sullivan, T. J., Harman, A. E. (1995). Attitude changes in DWI offenders: A study of a short-term treatment program. Journal of Addictions \& Offender Counseling, 15(2), 51-58.

Kim, K., Brunner, I. M., Yamashita, E. (2008). Modeling fault among accident-Involved pedestrians and motorists in Hawaii. Accident Analysis and Prevention, 40(6), 2043-2049.

Klauer, S. G., Dingus, T. A., Neale, V. L., Sudweeks, J. D., Ramsey, D. J. (2006). The impact of driver inattention on near-crash/crash risk: An analysis using the 100-car naturalistic driving study data. U.S. Department of Transportation, National Highway Traffic Safety Administration.

Kose, E. (2014). Cinsiyet, teknoloji ve kent: otomobilin muglak heteronormativizmi. Fe Dergi, 6(1), 32-42.

Lajunen, T., Parker, D., Summala, H. (2004). The Manchester Driver Behaviour Questionnaire: A cross-cultural study. Accident Analysis and Prevention, 36(2), 231-238.

Lawrence, C., Richardson, J. (2005). Gender-based judgments of traffic violations: The moderating influence of car type1. Journal of Applied Social Psychology, 35(8),1755-1773.

Ma, L., Yan, X. (2014) Examining the nonparametric effect of drivers' age in rear-end accidents through an additive logistic regression model. Accident Analysis and Prevention, 67, 129-136.

Mangiaracina, G., Palumbo, L. (2007). While driving and its consequences on road safety. Accident Analysis and Prevention, 19(3), 253-267.

Massie, D. L., Campbell, K. L., Williams, A. F. (1995). Traffic Accident involvement rates by driver age and gender. Accident Analysis and Prevention, 27(1), 73-87.

Mcevoy, S. P., Stevenson, M. R., Woodward, M. (2006). Phone use and crashes while driving: A representative survey of drivers in two Australian states. Medical Journal of Australia, 185(11-12), 630-634.

Newnam, S., Mamo, W. G., Tulu, G. S. (2014) Exploring differences in driving behaviour across age and years of education of taxi drivers in Addis Ababa, Ethiopia. Safety Science, 68, 1-5.

Ozdamar, K. (2016). Egitim, saglık ve davranıs bilimlerinde olcek ve test gelistirme yapısal esitlik modellemesi. Nisan Kitabevi Yayınları.

Ozkan, T., Lajunen, T. (2005). Multidimensional traffic locus of control scale (T-LOC): factor structure and relationship to risky driving. Personality and Individual Differences, 38(3),533-545.

Ozkan, T., Lajunen, T. (2006). What causes the differences in driving between young men and women? The effects of gender roles and sex on 
Analysis of Perceptions of Driver Abilities and Behaviors in Urban Transportation with Respect to Gender Identity

young drivers' driving behaviour and self-assessment of skills. Transportation Research Part F: Traffic Psychology and Behaviour, 9(4), 269-277.

Parker, D., Manstead, A. S. R., Stradling, S. G., Reason, J. T., Baxter, J. S. (1992). Intention to commit driving violations: An application of the theory of planned behavior. Journal of Applied Psychology, 77(1), 94-101.

Parker, D., Stradling, S. (2001). Influencing driver attitudes and behaviour: Road Safety. Research Report No. 17.

Preston, C. C., \& Colman, A. M. (2000). Optimal number of response categories in rating scales: reliability, validity, discriminating power, and respondent preferences. Acta Psychologica, 104(1), 1-15.

Ram, T., Chand, K. (2016). Effect of drivers' risk perception and perception of driving tasks on road safety attitude. Transportation Research Part F: Traffic Psychology and Behaviour, 42(1), 162-176.

Rhodes, N., Pivik, K. (2011). Age and gender differences in risky driving: The roles of positive affect and risk perception. Accident Analysis and Prevention, 43(3), 923-931.

Rosenbloom, T., Ben-Eliyahu, A., Nemrodov, D., Biegel, A., Perlman, A. (2009). Committing driving violations: An observational study comparing city, town and village. Journal of Safety Research, 40(3), 215219.

Rowe, R., Roman, G. D., Mckenna, F. P., Barker, E., Poulter, D. (2015). Measuring errors and violations on the road: A bifactor modeling approach to the driver behavior questionnaire. Accident Analysis and Prevention, 74, 118-125.

Sabbour, S. M., Ibrahim, J. M. (2010). Driving behavior, driver style and road traffic accidents among young medical group. Injury Prevention, 16(1), 1-13.

Sabey, B. E., Taylor, H. (1980). The known risks we run: the highway. In Societal Risk Assessment. Springer.

Santamarina-Rubio, E., Perez, K., Olabarria, M., Novoa, A. M. (2014). Gender differences in road traffic injury rate using time travelled as a measure of exposure. Accident Analysis and Prevention, 65, 1-7.

Shao, A. T., \& Zhou, K. Z. (2002). Marketing research: An aid to decision making. South-Western/Thomson Learning.

Shinar, D., Compton, R. (2004). Aggressive driving: An observational study of driver, vehicle, and situational variables. Accident Analysis and Prevention, 36(3), 429-437.

Sibley, C. G., Harre, N. (2009). A gender role socialization model of explicit and implicit biases in driving self-enhancement. Transportation Research Part F: Traffic Psychology and Behaviour, 12(6), 452-461. 
Silas, O. A., Adoga, A. A., Isichei, C., Echejoh, G. O., Manasseh, M. N., OluSilas, R. A. (2011). Road traffic accident deaths as seen in a Tertiary Health Centre Jos University Teaching Hospital (JUTH), Jos, North central, Nigeria. Journal of Clinical Pathology and Forensic Medicine, 2(2), 13-15.

Soliman, A., Alhajyaseen, W., Alfar, R., Alkaabi, I. (2018). Changes in driving behavior across age cohorts in an arab culture: The case of state of Qatar. Procedia Computer Science, 130, 652-659.

Stanton, N. A., Salmon, P. M. (2009). Human error taxonomies applied to driving: A generic driver error taxonomy and its implications for intelligent transport systems. Safety Science, 47(2), 227-237.

Stephens, A. N., Sullman, M. J. M. (2015). Trait predictors of aggression and crash-related behaviors across drivers from the United Kingdom and the Irish Republic. Risk Analysis, 35(9), 1730-1745.

Sullman, M. J., Paxion, J., Stephens, A. N. (2017). Gender roles, sex and the expression of driving anger. Accident Analysis \& Prevention, 106, 2330.

Taber, K. S. (2018). The use of Cronbach's alpha when developing and reporting research instruments in science education. Research in Science Education, 48(6), 1273-1296.

Tavris, D. R., Kuhn, E. M., Layde, P. M. (2001). Age and gender patterns in motor vehicle crash injuries: importance of type of crash and occupant role. Accident Analysis \& Prevention, 33(2), 167-172.

Teye-Kwadjo, E. (2011). Risk perception, traffic attitudes and behaviour among pedestrians and commercial minibus drivers in Ghana: A case study of Manya Krobo District. Master's thesis, Norwegian University of Science and Technology.

Ulutas, B., Sapaz, D., \& Dumanlı, D. (2015). Ulaşım sektöründe kadın emeği: Ankara'da çalışan kadın sürücü ve makinistler. Ankara Üniversitesi Eğitim Bilimleri Fakültesi Dergisi 48(2), 141-164.

Unal, L., Ozdek, N., Unal, N., Kececi, B. (2017). Those women drivers again, cliché, being a woman in traffic. International Journal of Traffic and Transportation Safety, 3(1), 88-109.

Vanlaar, W., Yannis, G. (2006). Perception of road accident causes. Accident Analysis and Prevention, 38(1), 155-161.

Wang, B., Hensher, D. A., Ton, T. (2002). Safety in the road environment: A driver behavioural response perspective. Transportation, 29(3), 253270 .

Wang, Y., Zhang, W., Reimer, B., Lavalliere, M., Lesch, M. F., Horrey, W. J., $\mathrm{Wu}, \mathrm{S}$. (2010). The effect of feedback on attitudes toward cellular phone use while driving: A comparison between novice and experienced drivers. Traffic Injury Prevention, 11(5), 471-477. 
Analysis of Perceptions of Driver Abilities and Behaviors in Urban Transportation with Respect to Gender Identity

Warner, H. W., Ozkan, T., Lajunen, T., Tzamalouka, G. (2011). Crosscultural comparison of drivers' tendency to commit different aberrant driving behaviours. Transportation Research Part F: Traffic Psychology and Behaviour, 14(5), 390-399.

Wolf, C. C., Ocklenburg, S., Oren, B., Becker, C., Hofstatter, A., Bos, C., Gunturkun, 0. (2010). Sex differences in parking are affected by biological and social factors. Psychological Research, 74(4), 429-435.

World Health Organization. (2013). Global status report on road safety 2013: supporting a decade of action: summary (No. WHO. NMH. VIP 13.01). World Health Organization.

Yeung, N. C. J., von Hippel, C. (2008). Stereotype threat increases the likelihood that female drivers in a simulator run over jaywalkers. Accident Analysis and Prevention, 40(2), 667-674.

Zhou, H., Zhao, J., Pour-Rouholamin, M., Tobias, P. A. (2015). Statistical characteristics of wrong-way driving crashes on illinois freeways. Traffic Injury Prevention, 16(8), 760-767.

\section{Resume}

Seher Özkazanç; Graduated from the Department of City and Regional Planning at the Faculty of Architecture at Gazi University in 2004. Received a master's degree in 2008 and a doctoral degree in 2016 from the Department of City and Regional Planning at Gazi University. She is currently working as an Assistant Professor at Necmettin Erbakan University since 2017. 